\title{
Practical value of genotypic analysis for diagnosing lymphoproliferative disorders
}

\author{
N T J O'CONNOR, * K C GATTER, $\dagger$ J S WAINSCOAT, J CRICK, * D B JONES, \\ G DELSOL, $\$$ E RALFKIAER, †† C DE WOLF-PEETERS, ${ }^{* *}$ B ANGUS,*** \\ D Y MASON $\ddagger$
}

\begin{abstract}
From the ${ }^{*}$ Medical Research Council Unit of Molecular Haematology, Nuffield Department of Clinical Medicine, the $\dagger$ Nuffield Department of Pathology, and the $\ddagger$ Department of Haematology, John Radcliffe Hospital, Oxford, the \University Department of Pathology, Southampton General Hospital, Southampton, the $\S$ Laboratoire Central d'Anatomie Pathologique, Toulouse, France, the ††Department of Pathology, The Finsen Institute, Copenhagen, Denmark, the **Academisch Ziekenhuis, Pathologische Ontleedkunde, Leuven, Belgium, and the ${ }^{* * *}$ Department of Pathology, Royal Victoria Infirmary, Newcastle upon Tyne
\end{abstract}

SUMMARY The value of DNA hybridisation (using immunoglobulin and $T$ cell receptor gene probes) was assessed during the diagnosis of problematical lymphoid tissue biopsy specimens. In 14 of 18 specimens $(78 \%)$, which contained a malignant lymphoproliferation of uncertain aetiology, this technique permitted the demonstration of a monoclonal proliferation of B cells (nine cases) or $\mathrm{T}$ cells (five cases). In five further lymph node biopsy specimens, in which the differential diagnosis lay between a reactive or malignant process, a clonal proliferation was shown in three cases. DNA analysis is, therefore, of practical value in resolving many of the diagnostic problems that arise in the assessment of lymphoid tissue biopsy specimens.

The availability of cDNA probes to immunoglobulin (Ig) and $\mathrm{T}$ cell receptor (TCR) genes provides a powerful tool for showing the clonality of $\mathbf{B}$ or $\mathrm{T}$ cell lymphoproliferative disorders. Studies with Ig gene probes have confirmed the $B$ cell origin of both common acute lymphoblastic leukaemia ${ }^{1}$ and hairy cell leukaemia. ${ }^{2}$ More recently, $T$ cell leukaemias $^{34}$ and lymphomas ${ }^{5-7}$ have been shown to undergo clonal rearrangements of the $\operatorname{TCR} \beta$ chain gene, and this phenomenon has been used to prove the $\mathrm{T}$ cell origin of Lennert's lymphoma ${ }^{8}$ and some cases of coeliac associated bowel lymphoma (previously believed to be a histiocytic malignancy). ${ }^{9}$

In spite of the obvious potential value of DNA probes in providing evidence for the $\mathrm{B}$ or $\mathrm{T}$ cell nature of a lymphoid proliferation it is not yet clear whether the combined use of Ig and TCR gene probes is of practical benefit in resolving the type of diagnostic problems faced by the histopathologist. Most of these difficulties fall into one of two categories: first, biopsy specimens which show a lymphoid neoplasm but in which the B or T cell nature of the lesion cannot be established by immunocytochemical labelling; and secondly, those specimens in which it is difficult to distinguish between a reactive and a malignant process.

It is clearly of considerable importance to establish how often DNA analysis with Ig and TCR probes will resolve these difficult cases, particularly as many histopathology laboratories with an interest in lymphoma are considering installing the relatively expensive and time consuming technology entailed.

In this paper we report our findings, using DNA analysis, to investigate a series of 23 problem lymphoid biopsy specimens, which had all given rise to difficulty after histological analysis and immunophenotyping.

\section{Material and methods}

SA M PLES

The biopsy specimens selected for study were those in which a firm pathological diagnosis was not possible after examination of routinely stained sections and immunohistologically labelled sections. The problems fell into two categories: the cell of origin of a neoplasm was unclear - that is, it could be B cell, $T$ cell, or histiocytic lymphoma or possibly non-lymphoid malignancy; it was impossible to differentiate between a reactive or neoplastic lymphoproliferative process. 
Table Results of DNA analysis of various lymph node biopsy specimens

\begin{tabular}{|c|c|c|c|c|c|c|c|}
\hline \multirow[b]{2}{*}{$\begin{array}{l}\text { Case } \\
\text { No }\end{array}$} & \multirow[b]{2}{*}{ Histological picture } & \multirow[b]{2}{*}{ Diagnostic problem } & & \multicolumn{3}{|c|}{ Genotypic data } & \multirow{2}{*}{ 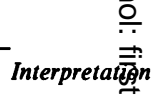 } \\
\hline & & & & $\overline{J_{\mathrm{H}}}$ & $C_{\mathrm{k}}$ & $T C R^{B}$ & \\
\hline 1 & Non-Hodgkin's lymphoma, pleomorphic & ?B or $\mathrm{T}$ cell & & $\mathbf{R}$ & $\mathbf{R}$ & G & B cell neop \\
\hline 2 & Non-Hodgkin's lymphoma, large + small cell & ?B or $\mathrm{T}$ cell & & $\mathbf{R}$ & $\mathbf{R}$ & G & B cell neoplatsm \\
\hline 3 & Non-Hodgkin's lymphoma, large + small cell & ?B or T cell & & $\mathbf{R}$ & $\mathbf{R}$ & G & B cell neopsism \\
\hline 4 & Non-Hodgkin's lymphoma, large cell & ?B or $\mathrm{T}$ cell & & G & $\mathbf{R}$ & $\mathbf{G}$ & B cell neopfasm \\
\hline 5 & Non-Hodgkin's lymphoma, pleomorphic & ?B or $\mathrm{T}$ cell & & $\mathbf{R}$ & $\mathbf{R}$ & $\mathbf{R}$ & B cell neoplasm \\
\hline 6 & Non-Hodgkin's lymphoma, large cell & ?B or $\mathrm{T}$ cell & & $\mathbf{R}$ & $\mathbf{R}$ & G & B cell neopłasm \\
\hline 7 & Non-Hodgkin's lymphoma, pleomorphic & ?B or $\mathrm{T}$ cell & & G & $\mathbf{R}$ & G & B cell neoptasm \\
\hline 8 & Non-Hodgkin's lymphoma, pleomorphic & ?B or T cell & & G & G & $\mathbf{R}$ & T cell neoplasm \\
\hline 9 & Non-Hodgkin's lymphoma, pleomorphic & ?B or $\mathrm{T}$ cell & & G & G & $\mathbf{R}$ & $T$ cell neoptasm \\
\hline 10 & Non-Hodgkin's lymphoma, large + small cell & ?B or T cell & & G & G & $\mathbf{R}$ & T cell neophasm \\
\hline 11 & Non-Hodgkin's lymphoma, large + small cell & ?B or $\mathrm{T}$ cell & & G & G & $\mathbf{R}$ & T cell neoptasm \\
\hline 12 & Non-Hodgkin's lymphoma, pleomorphic & ?B or $\mathrm{T}$ cell & & G & G & G & Inconcluside \\
\hline 13 & Non-Hodgkin's lymphoma, pleomorphic & ?B or $\mathrm{T}$ cell & & G & G & G & Inconclusipe \\
\hline 14 & Non-Hodgkin's lymphoma, large cell & ?B or $\mathrm{T}$ cell & & G & G & G & Inconclusiye \\
\hline 15 & Non-Hodgkin's lymphoma, pleomorphic & ?B or $\mathrm{T}$ cell & & G & G & G & Inconclusive \\
\hline 16 & Malignant process & ?Thymoma or non-Ho & dgkin's lymphoma & $\mathbf{R}$ & $\mathbf{R}$ & G & B cell neophasm \\
\hline 17 & Lymphoma & ?Hodgkin's disease or & non Hodgkin's lymphoma & $\mathbf{R}$ & G & G & B cell neoppasm \\
\hline 18 & Lymphoma & ?Hodgkin's disease or & non Hodgkin's lymphoma & G & G & $\mathbf{R}$ & $T$ cell neoptasm \\
\hline 19 & Lymphoid proliferation & ?Reactive or malignan & & $\mathbf{R}$ & $\mathbf{R}$ & $\mathbf{R}$ & B cell neop \\
\hline 20 & Lymphoid proliferation & ?Reactive or malignan & & $\mathbf{R}$ & $\mathbf{R}$ & $\mathbf{G}$ & B cell neoplasm \\
\hline 21 & Lymphoid proliferation & ?Reactive or malignan & & G & $\mathbf{G}$ & $\mathbf{R}$ & T cell negrefssm \\
\hline 22 & Lymphoid proliferation & ?Reactive or malignan & & G & $\mathbf{G}$ & G & $\begin{array}{l}\text { ProbabR } \\
\text { reactive }\end{array}$ \\
\hline 23 & Lymphoid proliferation & ?Reactive or malignan & & G & G & G & $\begin{array}{l}\text { Probak } \\
\text { reactive? }\end{array}$ \\
\hline $\begin{array}{l}\text { All san } \\
\mathbf{G}=\mathbf{g}\end{array}$ & $\begin{array}{l}\text { Fresh unfixed biopsy specimens } \\
\text { from } 23 \text { cases studied by the } \\
\text { departments participating in this st } \\
\text { were obtained from lymph nodes }(n \\
\text { 3), spleen }(n=2) \text { and lung }(n= \\
\text { was snap frozen and stored at }-7 \\
\text { specimens were classified according } \\
\text { morphological criteria and were also } \\
\text { nohistologically, by staining cryost } \\
\text { monoclonal antibodies, as previou } \\
\text { Controls consisted of samples of tiss } \\
\text { of carcinoma and peripheral blood } \\
\text { caucasian volunteers. }\end{array}$ & $\begin{array}{l}\text { were obtained } \\
\text { histopathology } \\
\text { tudy. Specimens } \\
=17) \text {, skin }(\mathrm{n}= \\
\text { 1). The material } \\
70^{\circ} \mathrm{C} \text {. All biopsy } \\
\text { to conventional } \\
\text { analysed immu- } \\
\text { tat sections with } \\
\text { lsly described. }{ }^{10} \\
\text { sue from } 28 \text { cases } \\
\text { from } 36 \text { healthy }\end{array}$ & \multicolumn{5}{|c|}{ 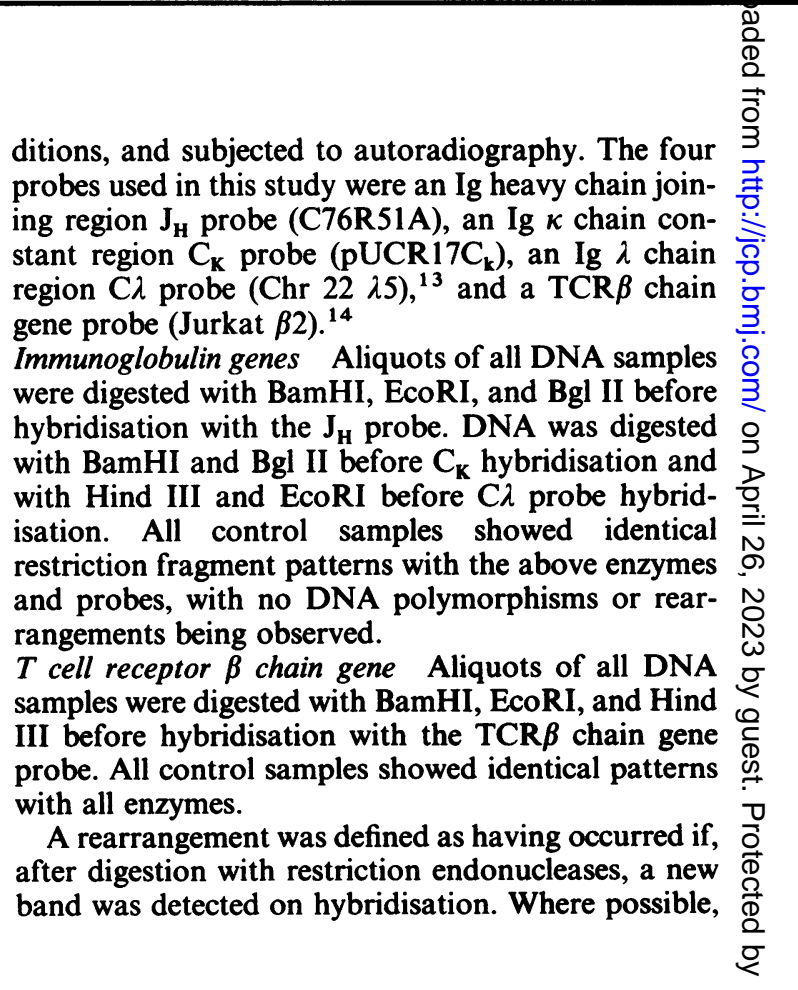 } \\
\hline
\end{tabular}


all rearrangements were shown using at least two different restriction enzymes to exclude the possibility of abnormal patterns being caused by DNA polymorphism.

\section{Results}

The table summarises the results of DNA analysis with Ig gene and TCR $\beta$ chain gene probes. Difficulties in diagnosis were divided into two categories as outlined below.

\section{MALIGNANT LYMPHOPROLIFERATIONS OF} UNCERTAIN CELL ORIGIN

In this category 15 cases were diagnosed histologically as non-Hodgkin's lymphomas, which could not be unequivocally assessed as being of either $B$ or $T$ cell origin after immunohistological staining (staining for $\kappa$ and $\lambda$ light chains had shown no clear pattern of light chain restriction). A clonal B cell population was shown by DNA analysis in seven cases (cases 1-7), in four of which numerous $T$ cells had been shown by immunohistological studies (leading to a suggested diagnosis of a T cell neoplasm). Case 5 showed both $\operatorname{TCR} \beta$ and Ig gene rearrangements, but as light chain gene rearrangement seems, from our own work and other data, ${ }^{1}$ to be restricted to B cell neoplasms, it is likely that this case was of $B$ rather than $T$ cell lineage. Four cases were shown to be $T$ cell derived nonHodgkin's lymphomas, while in four cases there was no evidence of a $B$ or $T$ cell clone.

In addition to these 15 cases, there were three cases in which the difficulty lay in distinguishing between a non-Hodgkin's lymphoma and a malignant process of non-lymphoid origin. In the first biopsy specimen (case 16) it was not possible to differentiate between a non-Hodgkin's lymphoma and a thymoma on morphological criteria, as leucocyte common antigen staining was negative. A clonal rearrangement of both Ig heavy and $\kappa$ light chain genes, however, provided objective evidence that the tumour was $B$ cell lymphoma. In two further cases the diagnosis lay between non-Hodgkin's lymphoma or Hodgkin's disease. Case 17 was a lymphoma arising in a patient with a history of Hodgkin's disease: at relapse the tumour had the appearance of Hodgkin's disease but seemed to contain a focus of high grade large cell non-Hodgkin's lymphoma, with the phenotypic pattern of a B cell neoplasm. DNA analysis confirmed the $B$ cell origin of this new tumour. In case 18 the differential diagnosis after morphological and immunohistological examination lay between a $T$ nonHodgkin's lymphoma and Hodgkin's disease with a large number of reactive T cells. Genotypic analysis on this case resolved the problem and provided objective evidence for a $\mathrm{T}$ cell neoplasm.
LYMPHOID PROLIFERATIONS

In cases 19 to 23 it was impossible to differentiate a reactive from a malignant process. In cases 19 and 20 clonal rearrangements of both heavy and light Ig chain genes showed the presence of B cell lymphoma. In case 21 a $T$ cell skin lymphoma was shown and in the last two cases DNA analysis showed a germline pattern with both $\operatorname{Ig}$ and TCR $\beta$ probes and was hence inconclusive.

\section{Discussion}

This study indicated that DNA analysis of tissue biopsy specimens from malignant lymphoproliferations of uncertain cell origin using Ig and TCR gene probes yielded an answer in most cases. In nine of 18 malignant lymphoid processes the neoplasm was shown to be of B cell origin. In four of these tumours the difficulty in diagnosis seems to have been caused by the presence of large numbers of reactive $T$ cells. The results of our study suggest that this may be a relatively common cause of difficulty in interpreting immunohistological analysis of lymphoma biopsy specimens. The cases probably correspond to the cases of "pseudo-T cell" non-Hodgkin's lymphoma, described by Arnold etal. ${ }^{15}$ These authors proved the existence of a monoclonal B cell proliferation in such tumours, as did the findings in our own study, by showing Ig gene rearrangement.

The availability of probes against the TCR $\beta$ chain gene now facilitates analysis of lymphoid neoplasms for evidence of possible $\mathrm{T}$ cell origin. ${ }^{3-5}$ From the findings in this study, however, it seems that cases of T non-Hodgkin's lymphoma, which give rise to diagnostic difficulty through masking by reactive normal cells, may be less common than B cell lymphoma (only five of 18 biopsy specimens were of $\mathrm{T}$ cell origin masked by reactive $B$ cells).

The cases in which no rearrangement could be shown were apparently all malignant (on morphological criteria) and showed histological and antigenic features (expression of the leucocyte common antigen) of lymphoma. As all B cell neoplasms seem to show Ig gene rearrangement these lymphomas are unlikely to be of B cell origin. It is thus conceivable that they are $\mathrm{T}$ cell neoplasms in which the $\beta$ chain gene has not undergone rearrangement (because they derive from an early maturation stage), or, alternatively, they may be of non-lymphoid origin, such as true histiocytic neoplasms. Further studies of tumours of this type are required to resolve these questions.

In addition to the 18 cases of lymphoma of uncertain origin, we studied DNA from five lymph node biopsy specimens in which there was dispute as to whether the histological picture was of a reactive 
lymphoid proliferation or a low grade lymphoma. A clonal lymphoid expansion was shown in three cases, supporting a diagnosis of lymphoma. This is in keeping with the rapid downhill course in cases 19 and 21 . In the two other cases no clonal rearrangements were detected, and although negative information of this type is open to several interpretations, the results support a reactive rather than a malignant lymphoid proliferation. This conclusion was supported by clinical follow up, in that both patients remained disease free after 20 and 24 months (the first received chemotherapy for six months and the second was not treated).

Finally, it should be noted that, although this study has shown the value of gene rearrangement studies in resolving diagnostic problems, the magnitude of this problem in diagnostic practice is relatively small. This is reflected in the fact that these cases were collected from six different centres. We estimate that less than $5 \%$ of lymph node biopsy specimens present difficulties in diagnosis after evaluation by histological and immunohistological procedures. It could therefore be argued that the most cost effective procedure is to establish facilities for DNA analysis in a limited number of centres. The present study entailed testing many biopsy specimens which had been sent on dry ice from different centres (in this country and abroad), and the logistical problems of transporting this type of material were relatively small. Consequently, centralisation of DNA studies in a few specialist centres is preferable to attempts to perform these techniques in a large number of smaller laboratories.

We are grateful to Professor DJ Weatherall for support and encouragement, Dr Tak Mak for $T$ cell receptor Jurkat $\beta 2$ probe, and Dr TH Rabbitts for the Ig gene probes. NTJOC is in receipt of a Medical Research Council training fellowship and KCG is a senior Wellcome Research Fellow. This work was also supported by grants from the Leukaemia Research Fund and Cancer Research Campaign.
References

1 Korsmeyer SJ, Arnold A, Bakshi A, et al. Immunoglobulin gene rearrangement and cell surface antigen expression in acute lymphoblastic leukaemias of T-cell and B-cell precursor origins. $J$ Clin Invest 1983;71:301-13.

2 Korsmeyer SJ, Greene WC, Cossman J, et al. Rearrangement and expression of immunoglobulin genes and expression of Tac antigen in hairy cell leukaemia. Proc Natl Acad Sci USA 1983;80:4522-6.

3 Minden MD, Toyonaga B, Ha Y, et al. Somatic rearrangement of $T$-cell antigen receptor gene in human $T$-cell malignancies. Proc Natl Acad Sci USA 1985;82:1224-8.

4 Flug F, Pelicci PG, Bonetti F, Knowles DM, Dalla-Favera R. $\mathrm{T}$-cell receptor gene rearrangements as markers of lineage and clonality in T-cell neoplasms. Proc Natl Acad Sci USA 1985;82:3460-4.

5 O'Connor NTJ, Wainscoat JS, Weatherall DJ, et al. Rearrangement of the $\mathrm{T}$-cell receptor $\beta$-chain gene in the diagnosis of lymphoproliferative disorders. Lancet 1985;i:1295-7.

6 Bertness V, Kirsch I, Hollis G, Johnson B, Bunn PA. T-cell receptor gene rearrangements as clinical markers of human T-cell lymphomas. $N$ Engl J Med 1985;313:534-8.

7 Weiss LM, Hu E, Wood GS, et al. Clonal rearrangements of T. cell receptor genes in mycosis fungoides and dermatopathic lymphadenopathy. $N$ Engl J Med 1985;313:539-44.

8 O'Connor NTJ, Feller AC, Wainscoat, JS, et al. T-cell origin of Lennert's lymphoma. Br J Haematol 1986;64:521-28.

9 Isaacson PG, O'Connor NTJ, Spencer J, et al. Malignan histiocytosis of the intestine: a T-cell lymphoma. Lance 1985;ii:688-91.

10 Gatter KC, Falini B, Mason DY. The use of monoclonal antibodies in histopathological diagnosis. Rec Adv Histopatho 1984;12:35-67.

11 Old JM, Higgs DR. Gene Analysis. In: Weatherall DJ, Clegg eds. The thalassaemia syndromes. Oxford: Blackwell Publicxô tions, 1981:200-14.

12 Feinberg AP, Vogelstein B. A technique for radiolabelling DNA restriction endonuclease fragments to high specific activity. Anal Biochem 1983;132:6-13.

13 Foroni L, Catovsky D, Rabbitts TH, Luzzatto L. DNA rearrangements of immunoglobulin genes correlate with phenotypic markers in B-cell malignancies. Mol Biol Med 1984; 2:63-79.

14 Yanagi Y, Yoshikai Y, Leggett K, Clark SP, Aleksander I, Mak TW. A human T cell-specific cDNA clone encodes a protein having extensive homology to immunoglobulin chains. Nature 1984;308:145-9.

15 Arnold A, Cossman J, Bakshi A, Jaffe ES, Waldman TA, Korsmeyer SJ. Immunoglobulin gene rearrangements as unique clonal markers in human lymphoid neoplasms. $N$ Engl J Med 1983;309:1593-9.

Requests for reprints to: Dr DY Mason, Department of Haematology, John Radcliffe Hospital, Oxford OX39DU, England. 